MONOGRAPH

Perspectives on the teaching of grammar: Curriculum, didactic proposals, and classroom practice

\title{
GRAMMAR AND TEXT PRODUCTION IN SECONDARY EDUCATION TEACHING MATERIALS OF BASQUE, SPANISH AND ENGLISH: REFLECTIONS ON AN INTEGRATED DIDACTICS OF LANGUAGES
}

\author{
Received: 31/03/2020 | Reviewed: 13/04/2020 | Accepted: 20/05/2020
}

\author{
Ibon MANTEROLA \\ Universidad del País Vasco / \\ Euskal Herriko Unibertsitatea \\ ibon.manterola@ehu.eus
}

\author{
Leire DÍAZ DE GEREÑU LASAGA \\ Universidad del País Vasco / \\ Euskal Herriko Unibertsitatea \\ leire.diaz@ehu.eus
}

\author{
Margareta ALMGREN \\ Universidad del País Vasco / \\ Euskal Herriko Unibertsitatea \\ xamaoik@gmail.com
}

\begin{abstract}
The goal of this paper is to offer a reflection on the integrated didactics of languages in the context of Basque multilingual education, based on the empirical analysis of a sample of teaching materials. The work focuses on some aspects of the production of expository text genres, selecting three teaching units in Basque, Spanish and English textbooks for first year of Secondary Education. It particularly explores how a specific feature of grammar such as linkers or text organisers is treated from a textual perspective. Some findings point out that the textbooks analysed share some common and coordinated criteria that open the path towards an integrated teaching of languages. The analysis also reveals that each of the textbooks follows a distinct tradition of text and grammar teaching. The paper concludes emphasizing the challenges derived from conceptual and methodological differences in the treatment of grammar, which affect the exploitation of text genre as a didactic resource and the implementation of an integrated didactics of languages.
\end{abstract}

Keywords: integrated didactics of languages; Basque multilingual education; text organisers; text production; teaching materials.

GRAMÁTICAY PRODUCCIÓNTEXTUAL EN MATERIALES DIDÁCTICOS DE EUSKERA, ESPAÑOL E INGLÉS DE SECUNDARIA: REFLEXIONES SOBRE UNA DIDÁCTICA INTEGRADA DE LENGUAS

Resumen: El objetivo de este artículo es ofrecer una reflexión sobre la didáctica integrada de lenguas en el contexto de la educación plurilingüe vasca, basada en un análisis de una muestra de materiales didácticos. En el presente trabajo se ha focalizado en algunos aspectos de la producción de géneros textuales expositivos, tal y como se proponen en unidades didácticas de euskera, español e inglés de primero de secundaria. Se ha analizado, desde un punto de vista textual, el tratamiento de un aspecto gramatical específico como los conectores $u$ organizadores textuales. Los resultados señalan que las unidades analizadas se basan en diversos criterios comunes y coordinados, lo que supone un avance hacia la didáctica integrada de lenguas. Asimismo, el análisis revela que cada unidad didáctica refleja una tradición distinta de la enseñanza del texto y de la gramática. El artículo concluye subrayando los retos derivados del hecho de que existan diferencias conceptuales y metodológicas en el tratamiento de la gramática. Estas diferencias afectan a la explotación del género textual como recurso didáctico, así como a la implementación de una didáctica integrada de lenguas.

Palabras clave: didáctica integrada de lenguas; educación plurilingüe vasca; organizadores textuales; producción textual; materiales didácticos.

\section{GRAMÄTICA I PRODUCCIO TEXTUAL EN MATERIALS DIDÀCTICS D'EUSOUERA, ESPANYOL I ANGLĖS DE SECUNDÀRIA: REFLEXIONS SOBRE UNA DIDA்CTICA INTEGRADA DE LLENGÜES}

Resum: Lobjectiu d'aquest article és oferir una reflexió sobre la didàctica integrada de llengües en el context de leducació plurilingüe basca, basada en lanàlisi d'una mostra de materials didàctics. En aquest treball ens centrem en alguns aspectes de la producció de gèneres textuals expositius, tal i com es proposen en unitats didàctiques d'eusquera, espanyol i anglès de primer de secundària. S'ha analitzat, des d'un punt de vista textual, el tractament d'un aspecte gramatical específic com els connectors o organitzadors textuals. Els resultats mostren que les unitats analitzades es basen en diversos criteris comuns i coordinats, cosa que suposa un avenç cap a la didàctica integrada de llengües. L'anàlisi també revela que cada unitat didàctica reflecteix una tradició diferent de lensenyament del text i de la gramàtica. Larticle conclou subratllant els reptes derivats del fet que existeixin diferències conceptuals i metodològiques en el tractament de la gramàtica. Aquestes diferències afecten l'explotació del gènere textual com a recurs didàctic, així com a la implementació d'una didàctica integrada de llengües.

Paraules clau: didàctica integrada de llengües; educació plurilingüe basca; organitzadors textuals; producció textual; materials didàctics. 


\section{Introduction}

This article aims at offering a reflection on the integrated didactics of languages (IDL) in the context of Basque multilingual education, based on the empirical analysis of a sample of teaching materials. We will analyse a sample of teaching materials of Basque, Spanish and English published for Basque secondary schools, and more precisely, the textbooks published by the association of Basque-medium schools Ikastolak under the name of the EKI Proiektua. We will focus on some aspects of the production of expository text genres, exploring how grammar is treated from a textual perspective in the three languages. We seek to observe the articulation between grammar and text production, an issue that, according to Bulea Bronckart (2016), has not yet found a satisfactory answer in language didactics.

Nowadays the Basque society is facing several challenges related to languages and education. On the one hand, the process of revitalizing a minorized language like Basque, in contact with a majority language - Spanish or French - has put great demands on the educational system during the last decades. On the other hand, the increasing need for linguistic skills in English must also be considered.

It is important to emphasize that Basque-medium education (be it immersion or maintenance programs) aims at promoting the competence to use Basque, Spanish - or French - and English in real communicative situations, as well as fostering positive attitudes towards linguistic diversity, especially towards minority languages (Idiazabal \& Dolz, 2013; Idiazabal et al., 2015).

This introductory section is followed by a general presentation of the sociolinguistic and educational context of Basque. Sections two and three refer to the theoretical background of the study: first, some didactic approaches to immersion and multilingual education are introduced. Next, the text-genre-based language didactics is explored, as well as the place of grammar in the teaching of text genre production. In section four, we will present the methodological aspects of the study, followed by the results, and finally, the conclusions.

\section{The sociolinguistic and educational context of Basque}

Basque is spoken along with the dominant languages Spanish and French in three different administrative communities: in the Basque Autonomous Community (henceforth BAC) and the Community of Navarre on the Spanish side of the Pyrenees, and in three provinces of the Basque Municipal Community, on the French side. Since it became official and compulsory in education in the BAC in 1982, a revitalisation process of the language has taken place through its progressive incorporation in the educational system. According to the last sociolinguistic survey (Basque Government, 2016), an estimated 53\% of the population of the BAC understands Basque, even though only about $34 \%$ are active speakers. In this article, we will only refer to the BAC.

Since the official introduction of Basque in education in the early ' 80 s, three linguistic models have been offered: the A model, with Spanish as language of instruction and Basque as a subject ( 3 to 4 sessions a week); the B model, where both Spanish and Basque are used as language of instruction; and the D model, where Basque is the language of instruction and Spanish is taught 
as a subject ( 3 to 4 sessions a week). Parents have the right to choose one of these models for their children, although excluding the big cities, in most areas the A model is not offered due to lack of demand. In the three models, English is present, in most cases as a subject matter, but it has also been introduced as language of instruction of a choice of subjects.

Basque is L1 for $20.5 \%$ of the population of the whole Basque Country (Basque Government, 2016). In the cases where Spanish is students' L1, the D model responds to an immersion model, whereas for children who speak Basque as L1, it constitutes a maintenance model (Idiazabal \& Dolz, 2013). It should be noted that, thanks to the influence of favourable public policies which have given good results (Cenoz, 2009), currently the overwhelming majority of parents choose the $\mathrm{D}$ or $\mathrm{B}$ model for their children in primary education. The $\mathrm{D}$ and $\mathrm{B}$ models have grown from around 25\% in 1984/85 to over $95 \%$ in 2018. The role of Basque-medium education is clearly reflected in the increase in Basque speakers among teenagers: around 54\% of young speakers of Basque in the BAC are L1 speakers of Spanish (Basque Government, 2016).

According to the curriculum of the BAC, students need to achieve a B1 level at the end of primary school (age 12) and a B2 level at the end of secondary school (age 16) in Basque and Spanish. For English, the B1 level is expected at the end of Secondary Education (Muñoa, 2019).

Overall, the good results of Basque-medium education have been confirmed by research on the linguistic and academic outcome (Cenoz, 2009; Cenoz \& Gorter, 2014), although very recently some standard evaluations such as PISA 2015-2018 have shown lower scores. Nevertheless, the positive trend throughout years together with the commitment of parents towards the learning of Basque by their children, are important in order to explain the rapid and continuous increase in the choice of the D model in the BAC.

\section{Didactic approaches to immersion and multilingual education}

Traditionally, immersion didactics was based on the idea that children should be provided as much input as possible from the immersion language. This implied that the $\mathrm{L} 1$ or home language should not be used in the classroom, keeping the language of immersion and the home language separate, following the so-called monolingual instructional approach (Cummins, 2008). However, recent research proposes a bilingual or even multilingual didactic perspective. The same author claims that new opportunities appear for bilingual instructional strategies in order to promote cross-linguistic transfer in bilingual students. This is the case, for instance, of translation, dual language book reading and the resource to students' L1 in very precise stages in the production of dual language identity texts (Naqvi et al., 2014).

A bilingual or even multilingual didactic perspective is also adopted by the so-called plural approaches to languages and cultures (Troncy, 2014), which support teaching and learning activities that imply the use of more than one linguistic variety (more than one language or more than one variety within a single language). One of the main proposals within this approach is that children need to work with more than one language together and the core type of activity is the comparison across languages in meta-linguistic activities (Candelier et al., 2012). This multilin- 
gual perspective should always take into account the specific attention needed so as not to endanger minorized languages (Cenoz \& Gorter, 2014; Idiabazal et al., 2015).

\subsection{Integrated Didactics of Languages}

A didactic approach closely linked to the previous ideas is the integrated didactics of languages (IDL). It consists of the design of multilingual curricula and teaching materials in order to enable language teachers to coordinate and base their teaching on common linguistic principles (Cavalli, 2005). Included among the pluralistic approaches (Candelier et al., 2012; Troncy, 2014), the IDL is based on the idea that unnecessary repetitions should be avoided in the teaching of languages, by fostering the economies of scale and the transfer of skills.

IDL implies coordination at the level of program organization, classroom activity design, assessment criteria and linguistic terminology and this requires that teachers base their teaching activity on common didactic principles (Apraiz et al., 2012; Cavalli, 2005; Dolz, 2005; Roulet, 1980).

The interdependence hypothesis postulated by Cummins may provide psycholinguistic explanations to the inter-linguistic influences referred in the IDL:

To the extent that instruction in Lx is effective in promoting proficiency in Lx, transfer of this proficiency to Ly will occur provided there is adequate exposure to Ly (either in school or environment) and adequate motivation to learn Ly. (Cummins, 1981:29).

In the Basque context, Aldekoa (2018) and Aldekoa et al. (2020) show that an integrated teaching of oral expository skills that includes activities in Spanish L1, Basque L2 and English L3 fosters the development of Secondary Education students' multilingual competence. Empirical data consist of initial and final expository texts produced in a didactic sequence. The analysis of text structure, topic introducers and use of verb tenses confirm that inter-linguistic and multidirectional discursive transfer constitutes a relevant didactic resource.

Within IDL, the expected outcomes for each language do not need to be identical. Instead, the sociolinguistic context should be considered when defining specific goals for each language teaching and learning, taking the presence and use of each language in society into account (Idiazabal \& Larringan, 2004; Dolz, 2005; Wokusch, 2008).

\subsection{Integrated Didactics of Languages in the BAC curriculum}

Following European guidelines, the basic curricula of the BAC for primary and Secondary Education include the approach of teaching Basque, Spanish and English in a coordinated and integrated way. The reference to text genres in the curricula also needs to be highlighted. Both curricula provide a teaching framework where real communicative contexts are promoted and texts are pointed out as teaching and learning objects in the domain of oral and written communication objectives.

Some trilingual or multilingual projects were developed during the last decade of the 20th 
century, using English as language of instruction for different school subjects (Cenoz, 2009). Integrated teaching of languages as a means of promoting multilingualism at school has since then also been encouraged by the Berritzegune Central del Departamento de Educación del Gobierno Vasco (Apraiz et al., 2012). Berritzegunes are educational training and innovation support centers. In this context, the possibilities offered by IDL may be conceived as an axe around which a global project involving the three languages is designed (Ortega \& Anakabe, 2015).

\section{Text-genre-based language didactics}

Following the theoretical principles of the socio-discursive interactionism (ISD), texts and text genres are conceived as relevant communicative and linguistic units for the acquisition of language use. Texts, considered the empirical counterpart of language use, constitute the tools that permit humans to participate in all kind of linguistic activities (Bronckart, 1996). Genres refer to the socio-historical conditions of text production that characterise the potentially unlimited language activities attested in a community during a determined time span, being socially recognised as a sort of common units. Genres may group together the immense variety of texts, following three criteria: the contents, the communicative structure and the configuration of linguistic units (Dolz \& Gagnon, 2010; Schneuwly \& Sales Cordeiro, 2016).

From a didactic perspective, the teaching of oral and written text production, based on text genres, enhances the acquisition of language use (Dolz \& Gagnon, 2010; Millar, 2011). It permits focusing on communication as well as on linguistic form: students learn how to produce texts in a communicative situation; they become aware of some features of specific communicative situations as well as of text structures and linguistic forms. Regarding IDL, this approach favours the identification of common as well as distinctive interlinguistic features of a given genre (Idiazabal et al., 2015).

Linguistic competence is narrowly related to the development of text comprehension and production skills, as pointed out in the Basque curriculum and the CERF (Common European Reference Framework). In order to develop textual skills, the text genre constitutes a relevant resource (Bronckart, 1996; Larringan, 2009). However, the use of text genres does not always imply a didactic approach that leads to relating the communicative, textual and grammatical dimensions of language (Bulea Bronckart, 2015b). In fact, Basque teaching materials show significant differences as to the presence and use of text genres (Garcia-Azkoaga et al., 2010). This may be explained by the fact that text genre is an essential but also abstract category and its description entails a non-resolved difficulty for linguistics and language didactics (Coutinho \& Miranda, 2009; Miranda \& Coutinho, 2015).

As far as the relevance of grammar in the teaching of text genres is concerned, its role is becoming an important didactic challenge. The interaction between text and grammar is an important conceptual issue as well as an added difficulty when designing activities in the classroom in order to relate these two levels, text and grammar (Bulea Bronckart et al., 2017). 
Thus, we may find notional and terminological contradictions, sometimes incompatible with coherent and sustainable educational systems (Bulea Bronckart, 2016). Concerning IDL, it is essential to overcome these theoretical difficulties in order to establish coherently integrated interlinguistic didactic approaches (Apraiz et al., 2012; Idiazabal et al., 2015).

\section{Methodology}

The Basque curriculum for the first course of Secondary Education attributes a specific weight to expository texts. Expository texts describe, explain and transmit information, making an audience understand a given phenomenon or event (Rosat, 1995). The communicative contexts where explanation takes place are typically the situations of knowledge transmission with a hierarchical relationship between interlocutors, where an expert knows more about the topic than the addressee. In such situations, the goal of the explanatory text is to balance the hierarchical position of the interlocutors by increasing the addressee's knowledge about the topic. Explanatory text genres may contain descriptive, narrative, explanatory and argumentative constituents.

\subsection{Research questions}

Our first research issue aims at establishing which expository text genres are proposed as teaching and learning objects in the EKI materials for Basque, Spanish and English for the first year of Secondary Education (12-13-year-old students). This will imply determining the communicative purpose and how the instruction for producing the text genres is given. It will also permit us to explore the degree of integration or coordination among the materials in the three languages. The same applies to the text planning. Is there a common perspective that makes an integrated treatment of the languages possible?

The following research questions deal with the role of grammar in the teaching of the production of expository text genres. We will focus on linkers or text organisers, given that they are the grammatical elements that are worked on in the three languages. We will use the term "linker" given that it is the one used in the English textbook. These forms serve to articulate the diverse segments of a text, such as paragraphs and sentences (Bronckart, 1996). The following research questions will guide the analysis: how are linkers treated and how are they related to the production of expository texts? Which aspects of linkers are assessed, and which are the common criteria for the three languages? Overall, which are the possibilities and limits for the integrated didactics of a grammatical aspect such as linkers, as related to text production?

\subsection{EKI Project: the textbooks analysed}

The teaching materials of the EKI Project (both digital and printed versions) referred to in this article have been published during the last ten years for the four years of Secondary Education (12- 
16 years) by the association of Basque-medium schools Euskal Herriko Ikastolak and the Basque Publishing House Ikaselkar. These materials constitute an important reference in the Basque educational system and our choice is justified by three main reasons: first of all, one of the core aspects of language teaching in the EKI materials is the production of written and oral texts, following Bronckart's (1996) socio-discursive interactionist approach and Adam's (1992) discourse typology. Each unit of the teaching materials aims at the students' mastering of communicative activities in accordance with text genres (Muñoa, 2019). Secondly, in these materials, grammar is integrated into the teaching of text production. In addition, the textbooks also offer separate exercises on different aspects of grammar, including translation and inter-linguistic activities using the other two official languages of the Basque Country: Spanish and French. Finally, the EKI materials seek to develop a general linguistic competence by comparing, contrasting and relating languages. In this sense, EKI materials aim at offering a common integrated curriculum, leading to a balanced integrated linguistic competence based on Muñoa, 2019).

In each language (Basque, Spanish and English), there are three didactic units for each year of Secondary Education. All didactic units contain three sections with abundant illustrations: the initial phase, the development phase and the final phase. In the initial phase, students are introduced to the general topic and the communicative project they will deal with. The target text is linked to a social activity and this requires that students are familiar with a given text genre. The development phase consists of several activities where diverse aspects of the topic and the communicative project are worked on. At the end of this phase, students are required to carry out the project initially introduced. Finally, the last phase of the didactic units refers to a new communicative project where students will have to apply what they have previously learnt.

The linguistic level of the materials is adapted to the expected competence of students for each language. In this context, it is interesting to point out that the textbooks of English do not emphasize the habitual grammar drills and exercises but are based on language use in communicative situations. The Basque units also include references to the specific situation of Basque as a minorized language.

In the following, we will focus the analysis on three didactic units of first year of Secondary Education, all of the published in 2014. The Basque unit, called Zaharrak berri ("Same old same old") corresponds to the third unit of the year and contains 67 pages. The unit of Spanish, Las lenguas y sus hablantes, constitutes the second unit of the year and contains 72 pages. Finally, in English, The secrets of the oceans is the second unit and contains 63 pages. The three units have been selected because they all correspond to the same educational level, and additionally, the three of them include an expository text genre as a teaching and learning target.

\section{Results}

Our analysis of the teaching units in the three languages reveals some common elements. However, a different written expository text is proposed in each language as teaching/learning object, and the communicative purpose is specified in different ways. 


\subsection{The communicative purpose and the instructions to produce the text genres}

In Basque, we find a complete presentation of the project at the beginning of the unit. The text genre to be produced is clearly specified through a fictional letter addressed to students ("you have to choose a topic related to the Basque traditions, you have to observe and analyse it in order to write an informative article"). It is also added that the addressees are young readers of a Basque journal about Basque culture and traditions.

A model of the target text is provided in the textbook in order to establish a contrast with other genres (news about carnivals and publicity about the same carnival). However, this model and the activities related to it do not provide students the opportunity to analyse the features of the genre.

In Spanish, the communicative project is introduced in the initial stage of the unit. Students are invited to find out which languages are spoken in their classroom and in their town, the reasons why speakers of different languages have come to live there and some characteristics of the languages in question. Based on this information, students are invited to produce two genres: a written report and an oral exposition in the classroom. The unit includes examples of oral interviews on different topics, where students learn diverse ways of collecting information. However, the information collected in the aforementioned activities is not used to produce the written report and the oral exposition.

As we can see, both in Basque and in Spanish the goal of the expository text and the specific genres are introduced in the initial phase, as well as the roles of the addressee and the producer and the social framework.

The initial phase of the unit for English presents a different approach as compared to both Basque and Spanish. The communicative purpose is presented at the beginning of the unit by just mentioning that the aim is to organize an exhibition on the secrets of the oceans. However, the form of the exhibition (whether an oral exhibition, or an oral exhibition with a written support) is not specified at this stage, neither for whom and where. These contextual elements are introduced drop by drop throughout the unit. At the end of the initial phase, there is an activity where a picture of a poster exhibition in a classroom setting and an oral explanation appear. The goal of this activity is to complete the information about the purpose of the exhibition the students will carry out. It is not until the second module that the students are told: "In the exhibition at the end of the unit, you will describe a sea creature". Throughout the unit, it is made clear that students are expected to produce an exhibition poster containing descriptive, narrative and expository sections. However, they are not provided a model of the whole exhibition that would gather these three sections.

We could summarize that in Basque and in Spanish, the text genre is clearly specified, whereas in English the references to the target genre are vaguer. Moreover, only the Basque textbook provides a model of the genre to be produced.

\subsection{Text planning}

The Basque textbook proposes a descriptive sequence as the planning structure for the informative 
article. Certainly, an informative article may contain description type sections and it is relevant that students learn how to produce them, but an informative article also needs other sections, such as an introduction and an ending. However, the planning of the informative article as a whole is not presented. This perspective can also be found in all assessment activities, where the communicative purpose and contents are much more prominent than the different sections of the structure of the informative article.

In the Spanish unit, there is no activity where the planning model of the written report is shown. Students are only given a pattern according to which they have to classify and select information as referred to the language and to its speakers. Throughout the unit, there are activities referring to accent marks (a problem also for native speakers), film and theater, before the pattern for structuring the information is recovered. Referring to the self-assessment activities, we find no explicit reference to the specific planning of the written report. The final self-assessment includes an explicit reference to the sections and subtitles of the written report, even if these aspects have not been practiced throughout the unit.

Finally, the English unit includes description, explanation and narration-based text planning. There is no specific activity focusing on the planning model of the whole exposition. The unit includes a video-recorded model of how to produce the exhibition, both in its written and oral forms. However, in the following, the three main parts of it (description of a sea creature, explanation of an ocean motion and narration of an ocean event) are worked on in an isolated way, without referring to the whole structure. Students are encouraged to practice the oral presentation, but they are not given any real guidelines.

\subsection{The use of linkers}

In Basque, mainly additive linkers ("moreover") and example introducers ("for instance", "among others") are worked on as a means of linking sentences and paragraphs. Even if the informative article genre is mentioned in a summary box, the two activities proposed only include isolated sentences to be linked by diverse linkers. These sentences can be identified as parts of the informative articles to be written by students, since they refer to cultural topics that could easily be related to such articles, and because this kind of information appears in previous activities of the unit. However, there is no explicit reference to the target genre. Regarding the self-assessment activities, they recover the use of linkers to add information and to introduce examples, but we find no more specific references to the use of these organizers in the target genre informative article. They only seem to refer to sentence-related uses of linkers.

In the Spanish unit, cause-consequence linkers are worked on. Before the first activity, there is a box where it is explained that the paragraph coherence requires the use of linkers within sentences and between sentences. This is followed by two activities. In the first activity, students need to distinguish the causes and consequences of personal situations in paragraphs that refer to the content of the target genre report (for instance, the reasons why someone has left her coun- 
try). Contrary to what we said for the activities in the Basque textbook, the instructions of this activity do explicitly mention the contents of the target genre report that students are working on throughout the unit.

In the next activity, students are required to rewrite the sentences of the first activity including cause-consequence structures (from the sentence "she left her country because she had no job" to "since she had no job she left her country"). For this activity, students are provided a summary box where the functions and forms of cause-consequence linkers are introduced. All examples in the activity and in the summary box include topics that are clearly related to the target genre report.

Some pages later, there is a third activity to work on linkers. Students are required to fill in the gaps of a text and discriminate cause-consequence linkers from other type of linkers. The instruction does not clearly refer to the target genre report. It just mentions the general term "text". The same happens in the self-assessment activity, where only a general reference to the use of correct linkers appear ("Complete the sentences and texts with correct linkers").

In the English textbook, the teaching of linkers appears in the sections where explanation of a process and narration of events are worked on. When referring to a process, linkers are included in an activity where the main goal is to explain why tsunamis happen and which are their consequences. Linkers are referred to as "the words" and no difference is made between linkers ("first", "then") and expressions of processes (such as "two tectonic plates collide" or "reach the shore"). The types of linkers worked on are temporal ("later", "then") and causal ("as a result"). Neither the goal of the unit (the production of a poster for an exhibition), nor its contents are referred to. However, the instruction of the activity refers to "explain to your partner", related to the type of discourse (explanation).

The approach of this activity seems to be acquisition of knowledge about ocean phenomenon, rather than working on expository texts in relation to a given context and a specific genre: no information is provided about the communicative context of the activity ("explain the process of a tsunami"), for instance, the addressee and the goal. There is no linking to the planning of the target genre and its marking by means of linkers.

In the case of the narration of events, after reading the text entitled "The adventures of Ferdinand Magellan", students are shown temporal linkers in an explanatory box entitled "Linkers in the narration". In this box, it is said that "We can link the text with words and expressions such as "on", "in", "after", "finally" etc.). In the next activity students have to re-write the eleven events of Magellan's journey, by using the linkers previously shown in the box. The target genre poster for an exhibition is not explicitly mentioned in either activity.

Concerning the assessment criteria, three checklists are distinguished, each for one section of the exhibition (description of a sea creature, explanation of a sea process, and narration of an event). Linkers appear in the last two sections, as they have not been worked on in the first one. However, the checklist just refers to "linkers to express process" and "time-linkers to organize the information chronologically", while the target genre exhibition that gathers the three sections is not mentioned. 


\section{Conclusions}

The goal of this paper was to explore the degree of coordination of three textbooks aiming at the teaching of expository text genres, based on the perspective of the integrated didactics of languages in the Basque multilingual educational context. We particularly focused on the treatment of grammar from a textual perspective in the three languages, seeking to observe the articulation between grammar and text production. On the one hand, we analysed how the communicative project to produce the target texts was introduced in the textbooks, as well as the activities related to the planning of the texts. On the other hand, we focused on how the work on linkers was proposed, in order to study the treatment of grammar as related to the teaching of text production.

However, prior to the conclusions related specifically to these aspects, we would like to emphasize that the three textbooks have an identical overall structure, composed of an initial phase, a development phase and a final phase. Seemingly, the three units are clearly based on the communicative approach in accordance with the Basque curriculum.

The fact that the communicative projects define distinct target expository text genres for each teaching unit avoids unnecessary repetitions of the same genre in the three languages. If we add this feature to the common general structure of the textbooks mentioned in the previous paragraph, we could emphasize that these textbooks show a degree of integration that opens the path towards IDL, as proposed by both Basque and CERF curricula.

However, a more detailed analysis of the communicative projects reveals distinct approaches that may hinder inter-linguistic integration. In the Basque and Spanish textbooks, the communicative purpose of the text production is presented at the beginning of the unit, whereas in English instructions are given gradually throughout the unit. We also found that a model of the text genre to be produced was only provided in the Basque textbook. This model is not retrieved in the other textbooks, although it might have been a good opportunity for an integrated perspective and it has been considered important to provide students with a model for text production (Johns, 2015).

On a meta-linguistic level, different terms are used in order to define text organisers: "linkers" and "words" in English, "conectores" in Spanish and "testu antolatzaileak" in Basque. As pointed out by Apraiz et al. (2012), common criteria for terminology is an important constituent of IDL and as we have seen, this principle is not fulfilled in the textbooks analysed.

The linkers selected for the three units do seem relevant for the production of the expository texts proposed. They are treated at two levels: at the inter-sentential level and at the level of types of sequences proposed by Adam (1992). However, linkers are not worked on at the level of the overall structure of the target text genres. In this sense, our analysis reflects the difficulty of integrating the teaching of grammar at all levels of text structure (Bulea Bronckart et al., 2016) and we consider that this may hinder the development of interlinguistic didactic approaches such as IDL (Idiazabal et al., 2015).

On a general level, we might conclude that each of these textbooks follows a distinct tradition of text and grammar teaching. The theory of didactic transposition postulates the existence of specific patterns of language teaching, forged by tradition and objects of sedimentation throughout history (Aeby, 2014; Dolz \& Schneuwly, 2009). Following this theory, we may conclude that 
our analysis revealed the "sedimentation" of different teaching traditions in each of the languages.

In our opinion, the EKI materials certainly bring about new possibilities and open roads towards IDL in the context of Basque multilingual education. In addition, they clearly point out the challenges derived from conceptual differences and methodological difficulties in the treatment of grammar, which affect the exploitation of genre as a didactic resource and the implementation of IDL (Apraiz et al., 2012; Bulea Bronckart, 2015a).

\section{Ackowledgments}

This work has been carried out thanks to the financial support granted by the Basque Government [grant number IT983-16 /HIJE-2] and the University of the Basque Country (UPV/EHU) [grant number EHUA15-22]. We would also like to express our gratitude to the anonymous reviewers whose comments helped us improve our work.

\section{Refererences}

Adam, J. M. (1992). Les textes: types et prototypes: récit, description, argumentation, explication et dialogue. Paris: Nathan.

Aeby, S. (2014). Candide, La fée carabine et les autres. Vers un modèle didactique de la lecture littéraire. Bern: Peter Lang.

Aldekoa, A. (2018). Gure ikastola en tres languages: The teaching and learning of trilingual oral expository skills by means of a didactic sequence. Theory and Practice of Second Language Acquisition, 4(2), 73-92.

Aldekoa, A., Manterola, I., \& Idiazabal, I. (2020). A trilingual teaching sequence for oral presentation skills in Basque, Spanish and English. The Language Learning Journal. https://doi.org/10. $\underline{1080 / 09571736.2020 .1741666 .}$.

Apraiz, M.V., Pérez, M., \& Ruiz, T. (2012). La enseñanza integrada de las lenguas en la escuela plurilingüe. Revista Iberoamericana de Educación, 59, 119-137.

Basque Government (2016). VI Encuesta Sociolingüistica: Comunidad Autónoma Vasca. Vitoria-Gasteiz: Gobierno Vasco. Available at http://www.euskadi.eus contenidos/informacion/argitalpenak/es_6092/adjuntos/Resumen_VI_Encuesta_ Socioling\%C3\%BC\%C3\%ADstica_EAE_\%202016_1.pdf (Last access: 25/03/2019).

Bronckart, J.P. (1996). Activité langagière, textes et discours. Pour un interactionisme socio-discursif. Paris: Delachaux et Niestlé.

Bulea Bronckart, E. (2015a). L'interaction entre grammaire et texte : les défis didactiques d'une prescription innovante. SCRIPTA, 19(36), 57-74.

Bulea Bronckart, E. (2015b). Les genres et leurs "contre candidats" textuels et discursifs dans l'enseignement du français. Le Français dans le monde. Recherches et applications, 58, 66-74.

Bulea Bronckart, E. (2016). Théories du langage et didactique de la grammaire: réflexions autour d'un dialogue suivi. Education et Didactique, 10(3), 33-43. 
Bulea Bronckart, E., Gagnon, R., \& Marmy Cusin, V. (2017). L'interaction entre grammaire et texte, un espace d'innovation dans la didactique du français et la formation des enseignants. $L a$ Lettre de l'AIRDF, 62, 39-44.

Candelier, M. (Coord.), Camilleri-Grima, A., Castellotti, V., de Pietro, J.-P., Lõrincz, I., Meißner, F.-J., Noguerol, A \& Schröder-Sura, A. (2012). A framework of reference for pluralistic approaches to languages and cultures competences and resources. Graz: European Centre for Modern Languages.

Cavalli, M. (2005). Education bilingue et plurilinguisme. Le cas du Val d'Aoste. Paris: Didier.

Cenoz, J. (2009). Towards multilingual education. Basque educational research from an international perspective. Clevedon: Multilingual Matters.

Cenoz, J., \& Gorter, D. (2014). Multilingualism and European minority languages: The case of Basque. In D. Gorter, V. Zenotz \& J. Cenoz (Eds.), Minority languages and multilingual education: Bridging the local and the global (pp. 201-220). New York: Springer.

Coutinho, M. A., \& Miranda, F. (2009). To describe textual genres: problems and strategies. En Ch. Bazerman, A. Bonini \& D. Figueiredo (Eds.), Genre in a changing world. Perspectives on writing (pp. 35-55). Fort Collins, Colorado: The WAC Clearinghouse and Parlor Press.

Cummins, J. (1981). The role of primary language development in promoting educational success for language minority students. In California State Department of Education (Ed.), Schooling and language minority students: A theoretical framework. Los Angeles: Evaluation, Dissemination and Assessment Center, California State University,

Cummins, J. (2008). Teaching for transfer: challenging the two solitudes assumption in bilingual education. In J. Cummins \& N. H. Hornberger (Eds.), Encyclopedia of language and education. Bilingual education. Vol. 5. (pp. 65-75). New York: Springer.

Dolz, J. (2005). Implications didactiques de la proximité linguistique. In L. F. Prudent, F. Tupin \& S. Wharton (Eds.), Du plurilinguisme à lécole. Vers une gestion coordonnée desl langues en contextes éducatives sensibles. (pp. 341-358). Bern: Peter Lang.

Dolz, J., \& Gagnon, R. (2010). El género textual, una herramienta didáctica para desarrollar el lenguaje oral y escrito. Lenguaje, 38, 2, 497-527.

Dolz, J., \& Schneuwly, B. (2009). Des objets enseignés en classe de français : le travail de l'enseignant sur la rédaction de textes argumentatifs et sur la surbordonnée relative. Rennes: Presses universitaires de Rennes.

Dolz, J., Noverraz, M., \& Schneuwly, B. (2001). Séquences didactiques pour loral et pour lécrit. Notes méthodologiques (vol. II, $3^{\mathrm{e}} / 4^{\mathrm{e}}$ ). Bruxelles: De Boeck.

Garcia-Azkoaga, I., Imaz, A., Diaz de Gereñu, L., \& Alegria, A. (2010). Ahozkotasunaren irakaskuntza bigarren hezkuntzako testuliburuetan. Tantak, 22(1), 7-42.

Idiazabal, I., \& Dolz, J. (2013). Enseñar (lenguas) en contextos multilingües. Bilbao: Universidad del País Vasco/Euskal Herriko Unibertsitatea.

Idiazabal, I., \& Larringan, L.M. (2004). La competencia discursiva: una noción clave para la didáctica de las lenguas y la didáctica del plurilingüismo”. En A. M. Lorenzo, F. Ramallo \& X.P. Rogríguez-Yanez (Eds.), Bilingual socialization and bilingual language acquisition: 
Proceedings from the Second University of Vigo International Symposium on Bilingualism, 2002 (pp. 611-628). Vigo: Servizo de Publicacións da Universidade da Vigo.

Idiazabal, I., Manterola, I., \& Diaz de Gereñu, L. (2015). Objetivos y recursos didácticos para la educación plurilingüe. En I. Garcia-Azkoaga \& I. Idiazabal (Ed.), Para una ingeniería didáctica de la educación plurilingüe (pp. 39-59). Bilbao: UPV/EHU.

Johns, A. (2015). Students as Genre Scholars: ESL/EFL Classroom Approaches. In N. Artemeva \& A. Freedman (Eds.), Genre studies around the globe. Beyond the three traditions (pp. 364385). Inkshed Publications.

Larringan, L.M (2009). Testua, testu-generoa eta hizkuntzaren ikas-irakaskuntza. Euskera 45, (21), 505-539.

Millar, D. (2011). Promoting genre awareness in the EFL classroom. English Teaching Forum, 2011-2. 2-15.

Miranda, F., \& Coutinho, M. A. (2015). Les propriétés différentielles des genres et leurs implications didactiques / As propriedades diferenciais dos géneros e suas implicações didáticas. Recherches et Applications, 58, 17-26.

Muñoa, I. (2019). Konpetentzia digitalaren lanketa Hizkuntza arloan: EKI Proiektua. En M. Iruskieta, M. Maritxalar, A. Arroyo-Sagasta \& A. Camacho (Eds.), IKTak eta konpetentzia digitalak hezkuntzan (pp. 263-278). Bilbo: UEU.

Naqvi R., Schmidt E., \& Krickhan M. (2014). Evolving 50-50\% bilingual pedagogy in Alberta: what does the research say? Frontiers in Psychology, 5, 413. doi: 10.3389/fpsyg.2014.00413.

Ortega, A., \& Anakabe, M.J. (2015). Integración de lenguas y áreas desde proyectos globales: una propuesta de integración de las materias Conocimiento del Medio, Euskera, Lengua Castellana e Inglés. En I. Garcia-Azkoaga \& I. Idiazabal (Eds.), Para una ingeniería didáctica de la educación plurilingüe (pp. 291-319). Bilbo: Universidad del País Vasco/ Euskal Herriko Unibertsitatea.

Rosat, M.C. (1995). Un texte explicatif documentaire. Thèse de doctorat, Université de Genève.

Roulet, E. (1980). Langues maternelles, langues secondes. Vers une pédagogie intégrée. Paris: Hatier.

Schneuwly, B., \& Sales Cordeiro, G. (2016). Le genre de texte comme objet autonome d'enseignement: comparaison de deux approches didactiques. In G. Sales Cordeiro \& D. Vrydaghs (Eds.), Statuts des genres en didactique $d u$ français: recherche, formation et pratiques enseignantes (pp. 83-128). Namur: Presses universitaires de Namur.

Troncy, C. (Dir.) (2014). Didactique du plurilinguisme. Approches plurielles des langues et des cultures. Autour de Michel Candelier. Rennes: Presses Universitaires de Rennes.

Wokusch, S. (2008). Didactique intégrée des langues: La contribution de l'école au plurilinguisme des élèves. Babylonia, 2008-1, 12-14. 